\title{
Unilateral childhood blindness: a hospital-based study in Yaoundé, Cameroon
}

This article was published in the following Dove Press journal:

Clinical Ophthalmology

12 August 2009

Number of times this article has been viewed

\section{André Omgbwa Eballe' \\ Emilienne Epée ${ }^{2}$ \\ Godefroy Koki \\ Lucienne Bella ${ }^{2}$ \\ Côme Ebana Mrogo²}

'Faculty of Medicine and

Pharmaceutical Sciences, University of Douala, Douala, Cameroon; ${ }^{2}$ Faculty of Medicine and Biomedical Sciences, University of Yaoundé I, Yaoundé, Cameroon
Correspondence: André Omgbwa Eballe Ophthalmology unit, Gynaeco-Obstetric and Paediatric Hospital of Yaoundé, PO Box 4362, Yaoundé, Cameroon $\mathrm{Tel}+23799654468$

Fax +23722 21 2430

Email andyeballe@gmail.com
Introduction: We performed an analytic and prospective study over a period of 12 months from January 2nd to December 31st, 2008, at the Gynaeco-Obstetric and Paediatric Hospital of Yaoundé, Cameroon. Our aim was to determine the prevalence and causes of unilateral blindness in school children aged 6 to 15 years.

Results: Among the 1,266 children aged 6 to 15 years who were recruited, 60 presented with unilateral blindness (4.7\%): 42 boys $(6.96 \%)$ and 18 girls $(2.71 \%)$. The mean age was $10.15 \pm 3.4$ years. In patients with unilateral blindness, $65 \%$ was due to ocular trauma.

Discussion: The hospital-based prevalence of unilateral blindness in children is relatively high and ocular trauma is the leading etiology.

Conclusion: Unilateral blindness in school children is avoidable and its incidence could be markedly reduced by emphasizing an information strategy and education based on prevention of ocular trauma. Early management of nontraumatic diseases such as infantile glaucoma and some tumors could improve outcome and avoid blindness.

Keywords: unilateral blindness, ocular trauma, prevalence, education

\section{Introduction}

The age range of 6 to 15 years corresponds to a very sensitive period of life when children start going to school and discover themselves and have experiences. Any handicap or impairment occurring during that time may have a heavy psychosocial impact on the child, especially in their quality of life. Living with visual impairment is a very sad experience for the child. Visual impairment restricts the child's activities, especially during play or study. Three percent of blind worldwide are children. ${ }^{1}$ Many causes of childhood blindness can be prevented or treated. ${ }^{2}$ The prevalence of childhood blindness is usually estimated at 0.8 per 1,000 children. ${ }^{3}$ Nearly 500,000 children become blind each year; consequently the fight against childhood blindness has become a priority for the Vision 2020 Global Initiative. ${ }^{4}$ In Cameroon, little has been published on unilateral blindness in childhood in its epidemiological aspect. For that reason, we decided to look for the causes of unilateral childhood blindness in school pupils aged 6 to 15 years.

\section{Material and methods}

We conducted a prospective and analytic study over a period of twelve months from January 2nd to December 31st, 2008 at the Gynaeco-Obstetric and Paediatric Hospital of Yaoundé, Cameroon. Recruited candidates were school-attending children aged 6 to 15 years and presenting for the first time in our ophthalmology outpatients 
consultation clinic. Consents from parents or guardians were obtained before including the candidates in the study. All children underwent a complete comprehensive ocular exam to build a patient history with emphasis on the present complaint, history of the complaint, ocular history, and past medical history. Visual acuity was assessed for near and far vision in one eye at a time using the Snellen eye chart for the older patients and the Tumbling "E" or Landolt "C" chart for the younger patients, slit lamp examination of the anterior and posterior segment, and evaluation of intraocular pressure with an air pulse tonometer.

The World Health Organization (WHO) defines childhood blindness as visual acuity less than 3/60 in the better eye with the best-corrected visual acuity in children aged 0 to 15 years. ${ }^{3}$ We considered every child presenting with visual acuity less than $3 / 60(1 / 20)$ in one eye and the other eye having a visual acuity superior or equal to $6 / 18(3 / 10)$ to be unilaterally blind. The data analyzed using the Epi Info ${ }^{\text {TM }} 6.04$ program (Centers for Disease Control and Prevention, Atlanta, GA, USA) were: age, sex, past history, visual acuity with best correction, unilateral blindness and its etiology. The parents or guardians of the recruited patients had to complete a questionnaire, which included, among other information, the future occupation or profession they wished for their children. As a reference, we used the WHO anatomical classification of childhood blindness and its etiology. ${ }^{4}$ The chi-squared test was used for comparison and was considered significant if $\mathrm{p}<0.05$.

\section{Results}

\section{Prevalence}

A total of 1,266 children aged 6 to 15 years were examined: 663 girls (52.37\%) and 603 boys (47.63\%) (Table 1). Among these children, 60 were diagnosed unilaterally blind (a hospital prevalence of 4.7\%: 42 boys [6.96\%], 18 girls [2.71\%], and a sex ratio $\mathrm{M} / \mathrm{F}$ of $2.33 ; \mathrm{p}=0.0037)$. The mean age was $10.15 \pm 3.4$ years. The age group of 11 to 15 years (33 children, 4.41\%) was the most represented followed by the 6 to 10 years (27 children, 5.2\%) (Table 2$)$. The statistical difference was not significant $(p=0.7)$. The right eye was more affected in 39 cases $(65 \%)$ while the left eye was registered in 21 cases $(35 \%)(p=0.01)$.

\section{Past history, pathologies, and causes of unilateral blindness}

Examination of the events surrounding the origin of the child's ocular problem and latter blindness revealed episodes of trauma in 39 cases $(65 \%)$ out of the 60 cases of unilateral blindness $(p=0.000)$. One hundred eight of
Table I Age and sex distribution of all children consulted

\begin{tabular}{llll}
\hline Sex/Age & Boys & Girls & Total \\
\hline 6-10 years & $282(22.27 \%)$ & $237(18.73 \%)$ & $519(41 \%)$ \\
II-15 years & 32 I (24.6\%) & $426(33.6 \%)$ & $747(59 \%)$ \\
Total & $603(47.63 \%)$ & $663(52.37 \%)$ & $1266(100 \%)$ \\
\hline
\end{tabular}

the 1,266 children $(8.53 \%)$ had history of ocular trauma ( 88 had contusions [ $81.48 \%$ ] and 20 had penetrating injuries [18.52\%]). Boys were relatively more involved than girls especially in blinding traumas $(p=0.05)$. Nontraumatic ocular pain before blindness were mentioned in 12 cases $(20 \%)$ followed by proptosis in six cases $(10 \%)$ and three cases of monocular blindness occurred in a "white" eye with progressive loss of vision (Table 3). According to the WHO anatomical classification of etiologies of blindness, etiologies of unilateral blindness in children (Table 4) were more often represented by pathologies of the uveal tissues in 15 cases (25\%): nine cases of endophtalmitis following penetrating trauma, three cases of panuveitis, and three of traumatic hyphemas. These were followed by lesions of the lens with 12 cataracts $(20 \%)$ among which were 11 cases of trauma and one congenital unilateral cataract. In the third position, pathologies involving the whole globe were found in nine cases (15\%) composed of eight phthisis bulbi and one traumatic avulsion of the globe. Six cases $(10 \%)$ of orbital tumors with a prevalence of $0.47 \%$ were the causes of unilateral blindness. Among those six cases, Burkitt's lymphoma was diagnosed twice and the other four cases could not be determined by differentiation. With a prevalence of $0.71 \%$, the nine cases of glaucoma were of infantile asymmetric glaucoma in eight cases and one case of unilateral traumatic glaucoma in a terminal stage.

\section{Discussion}

\section{Prevalence}

We found a prevalence of $4.7 \%$ for unilateral blindness in children aged 6 to 15 years in our hospital-based

Table 2 Age and sex distribution of children with unilateral blindness

\begin{tabular}{|c|c|c|c|c|c|}
\hline \multirow[t]{2}{*}{ Age } & \multicolumn{5}{|c|}{ Sex } \\
\hline & \multicolumn{2}{|c|}{ Boys } & \multicolumn{2}{|c|}{ Girls } & \multirow{2}{*}{$\begin{array}{l}\text { Total } \\
27(5.20 \%)\end{array}$} \\
\hline $6-10$ years & 18 & $6.40 \%$ & 9 & $3.80 \%$ & \\
\hline $11-15$ years & 24 & $7.50 \%$ & 9 & $2.10 \%$ & 33 (4.4I\%) \\
\hline Total & 42 & $6.96 \%$ & 18 & $2.71 \%$ & 60 (4.70\%) \\
\hline
\end{tabular}


Table 3 Distribution of events mentioned before the unilateral blindness

\begin{tabular}{lll}
\hline History & N & $\%$ \\
\hline Ocular trauma & 39 & 65 \\
Nontraumatic ocular pain & 12 & 20 \\
Proptosis & 6 & 10 \\
None & 3 & 5 \\
Total & 60 & 100 \\
\hline
\end{tabular}

Cameroonian population. This prevalence is about two and a half times higher than the prevalence reported in the general Cameroonian population in $1993 .{ }^{6}$ In the same study, the authors published a level of unilateral blindness of $0.1 \%$ in the age group of 5 to 19 years, which is fifty times less than our findings. Our hospital-based prevalence is five times higher than the findings in a community-based study in Ethiopia where the reported prevalence of unilateral childhood blindness was $1 \%{ }^{7}$ These marked differences could be explained by the studied population and the site of recruitment. We report results of a hospital-based study while the Ethiopia study reported those of a population-based study which represented a mixture of healthy and unhealthy people. Compared to a hospital-based study undertaken among working young adults in Bamako, Mali, ${ }^{8}$ where the prevalence of unilateral blindness was $11.5 \%$, this was two and half times higher than ours. This suggests that the rate of unilateral blindness is more frequent in working young adults than in school pupils. In the Bamako series, the group of working

Table 4 Anatomical causes of unilateral blindness

\begin{tabular}{llll}
\hline Anatomical site & Pathologies & N & $\%$ \\
\hline Uvea & Panuveitis & 3 & \\
& Endophtalmitis & 9 & $25 \%$ \\
Anterior chamber & Hyphema & 3 & \\
Lens & Cataract & 12 & $20 \%$ \\
Cornea & Corneal opacities & 6 & $10 \%$ \\
& and hematocornea & & \\
Irido corneal angle & Glaucoma & 9 & $15 \%$ \\
Optic nerve & Optic neuropathies & 3 & $5 \%$ \\
Whole eyeball & Traumatic avulsion & 1 & \\
& of the eyeball & & \\
Orbit & Phthisis bulbi & 8 & $15 \%$ \\
Total & Orbital tumors & 6 & $10 \%$ \\
\hline
\end{tabular}

young adults was represented by farmers and illiterates who were exposed to risk factors such as the great distance from their homes to the health centers, exposure to the risk of further trauma, and other factors.

\section{Sex, age, and past history}

Boys were more affected than girls. This matches the results of Migliani and colleagues ${ }^{6}$ whose $\mathrm{M} / \mathrm{F}$ ratio was 1.71 in the age group of 5 to 19 years. The predominance of boys can be explained by their recorded history: $65 \%$ of unilateral blindness was caused by a great diversity of ocular trauma. Boys can be more aggressive and violent and have more active experiences than girls. This is why they are more affected $^{9}$ and because of their boldness, boys are often punished by parents, guardians, or school teachers, during which ocular trauma also occur. ${ }^{9}$ Child corporal punishment is still standard practice for correction in Cameroon whether in schools or at home; these are traditional methods of education in which people believe, despite the fact that they have been identified as major causes of traumas, ${ }^{10,11}$ especially ocular trauma in childhood. ${ }^{9,12,13}$ All age groups are affected by unilateral blindness $(\mathrm{p}=0.7)$. The right eye was more affected $(p=0.01)$. We could not explain the predominance of unilateral blindness in the right eye, but the possible cause may be trauma coming from the left hand of people or parents when fighting or receiving corporal punishment.

\section{Pathologies and causes of unilateral blindness}

Compared to our findings where trauma was the leading causes of unilateral blindness, the most common causes of unilateral childhood blindness in a Saudi Arabia study, 5 included trauma (30\%), retinal diseases (17\%), and refractive errors (15\%). In Ethiopia, corneal scarring contributed to $62.5 \%$ of unilateral blindness ${ }^{7}$ compared with our study where corneal opacities contributed to $10 \%$ of unilateral blindness. Corneal opacities were ranked number four in our series, and were mostly due to traumas and diseases such as corneal ulcers neglected by parents. Uveal involvement and pathologies of the lens (cataract) were complications of ocular traumas and the leading pathologies in unilateral blindness according to our results. With a prevalence of $0.4 \%$, orbital tumors have a bad vital as well as functional prognosis according to the degree of malignity. Burkitt's lymphoma is the most frequent orbital tumor in childhood according to the African literature ${ }^{14-16}$ and our results support this frequency. 
In our third rank after cataract is unilateral blindness due to infantile glaucoma, which is the result of a quiet and slow-growing process specific to this pathology. When the decreased vision is observed, amblyopia has already taken place with severe damage to the optic nerve head. ${ }^{17}$

\section{Occupations that parents hope for their children}

Parents with children diagnosed with unilateral blindness hoped that their children would find future occupations as medical practitioners $(40 \%)$, aircraft pilots $(25 \%)$, soldiers (20\%), lawyers (10\%), and secretaries (5\%).

Most of these occupations require good binocular visual acuity and many of these dreams will hardly be realized. The ocular traumas causing up to $65 \%$ of unilateral blindness in our series should be discussed, condemned, and prevented in families as well as in schools. In their study of the epidemiological aspect of ocular traumas in Abidjan, Cote d'Ivoire, Mensah and colleagues ${ }^{18}$ reported a rate of unilateral blindness of $64.5 \%$ before management, which improved to $55 \%$ after adequate treatment.

\section{Conclusion}

This hospital-based study is the first in our Hospital. It helped us to acknowledge the high rate of unilateral blindness among children in Cameroon, $65 \%$ of which is due to ocular trauma. These cases of blindness are avoidable and their incidence could be reduced if strategies of education and increasing awareness about the implications and the visual outcome of ocular trauma among parents, teachers, and children are put in place with strong emphasis. On the other hand, early and adequate management of nontraumatic ocular pathologies in childhood such as orbital tumors and infantile glaucoma will considerably reduce their poor vital and functional prognosis for vision in children.

\section{References}

1. Gogate P, Gilbert C. La cécité infantile: panorama mondial. Revue de Santé Oculaire Communautaire. 2008;5(6):37-39.

2. Gilbert C, Rahi J, Quinn G. Visual impairment and blindness in children. In: Johnson GJ, Minassian DC, Weale RA, West SK, editors. Epidemiology of Eye Disease. 2nd ed. London, UK: Hodder Arnold; 2003.

3. Gilbert C, Foster A. Blindness in children: control priorities and research opportunities. Br J Ophthalmol. 2001;85:1025-1027.

4. World Health Organization. Preventing blindness in children. Report of a WHO/IAPB scientific meeting, Hyderabad, India, 13-17 April 1999. Geneva, Switzerland: World Health Organization; 2000.

5. El-Sheikh HF, Tabbara FK. Childhood blindness in Saudi Arabia [abstract]. Invest Ophthalmol Vis Sci. 2002;43:3846.

6. Migliani R, Louis JP, Audugé A, Trebucq A, Gelas H. Evaluation de la malvoyance et des cécités au Cameroun: enquête en milieu rural forestier. Santé. 1993;3:17-23.

7. Shaffi M, Bejiga A. Common eye diseases in children of rural community in Goro district, Central Ethiopia. Ethiop J Health Dev. 2005;19:148-152.

8. Omgbwa Eballe A, Boitte JP, Traoré J. Les affections oculaires cécitantes du sujet en âge d'activité professionnelle: Institut d'ophtalmologie tropicale de l'Afrique (IOTA, Bamako, Mali) Santé. 2005; 15:241-245.

9. Omgbwa Eballe A, Kammy Gilles L, Assumpta Bella L. Les traumatismes oculaires de l'enfant consultant à l'hôpital gynéco obstétrique et pédiatrique de Yaoundé. Aspects épidémiologiques. Clinics in Mother and Child Health. 2006;3:433-436.

10. Johnson CF. Child maltreatment 2002: recognition, reporting and risk. Pediatr Int. 2002;44:554-560.

11. Youssef RM, Attia MS, Kamel MI. Children experiencing violence. II: Prevalence and determinants of corporal punishment in schools. Child Abuse Negl. 1998;22:975-985.

12. Oluwakemi AB, Kayode A. Corporal punishment-related ocular injuries in Nigerian children. J Indian Assoc Pediatr Surg. 2007;12:76-79.

13. Nwosu SN. Domestic ocular and adnexal injuries in Nigerians. West Afr J Med. 1995;14:137-140.

14. Prall FR, Hink EM, Liang X, Durairaj VD. Rapid onset proptosis and vision loss as the initial presentation of Burkitt lymphoma. Ophthalmic Surg Lasers Imaging. 2008;39:331-334.

15. Adeoye AO, Durosinmi MA, Adeodu OO, et al. Ocular manifestations of Burkitt's lymphoma: experience in Ile-Ife south western Nigeria. West Afr J Med. 2007;26:48-52.

16. Ntim-Amponsah CT. Ocular tumours and problems in management: a Ghanaian experience. East Afr Med J. 1996;73:182-186.

17. Kargi SH, Koc F, Biglan AW, Davis JS. Visual acuity in children with glaucoma. Ophthalmology. 2006;113:229-238.

18. Mensah A, Fany A, Adjorlolo C, et al. Epidémiologie des traumatismes oculaires de l'enfant à Abidjan. Santé. 2004;14:239-243.
Clinical Ophthalmology

\section{Publish your work in this journal}

Clinical Ophthalmology is an international, peer-reviewed journal covering all subspecialties within ophthalmology. Key topics include: Optometry; Visual science; Pharmacology and drug therapy in eye diseases; Basic Sciences; Primary and Secondary eye care; Patient Safety and Quality of Care Improvements. This journal is indexed on Submit your manuscript here: http://www.dovepress.com/clinical-ophthalmology-journal

\section{Dovepress}

PubMed Central and CAS, and is the official journal of The Society of Clinical Ophthalmology (SCO). The manuscript management system is completely online and includes a very quick and fair peer-review system, which is all easy to use. Visit http://www.dovepress.com/ testimonials.php to read real quotes from published authors. 